\title{
Influence of feed quan tity offered on growth performance, carcass yield, organs weight and back-fat composition of finishing pigs \\ C.P. ${ }^{*}{ }^{1}$ Njoku, A.B.J. ${ }^{1}$ Aina, O.M. ${ }^{1}$ Sogunle, O.A. ${ }^{1}$ Adeyemi, and O.O. ${ }^{2}$ Oduguwa \\ ${ }^{1}$ Department of Animal Production and Health, University of Agriculture, Abeokuta ${ }^{2}$ Department of Animal Nutrition, University of Agriculture, Abeokuta \\ *Corresponding author:ncfred0859@yahoo.co.uk $+2348034647741,+2348023741145$
}

\begin{abstract}
A study was conducted to determine the effect of feed quantity offered $(1.5,2.0$ or $2.5 \mathrm{~kg}$ ) on growth performance, carcass yield, organs weight and backfat composition. A total of 48 Large White grower male pigs with initial average weight of $36.48 \pm 2.25 \mathrm{~kg}$ were allotted to 3 treatments of 16 pigs per treatment and were further replicated into 4 with 4 pigs per replicate. Data were collected on weekly basis and carcass characteristics were performed when the pigs on each experimental group attained an average weight $70 \mathrm{~kg}$. Final body weight, daily weight gain and daily feed intake were significantly $(P<0.05)$ increased by feeding level with highest mean values obtained by the pigs fed $2.5 \mathrm{~kg}$ feed daily. Pigs on $1.5 \mathrm{~kg}$ daily feeding level took 108.31 days to attain the target weight of 70 $\mathrm{kg}$ which was significantly $(P<0.05)$ longer than 92.23 and 79.94 days obtained by those on 2.0 and $2.5 \mathrm{~kg}$ daily feeding levels respectively. Most of the parameters considered for carcass yield were not significantly $(P>0.05)$ enhanced by feed quantity offered. The weight of ham $(11.54,12.18$ and 13.41 $\%)$ increased significantly $(P<0.05)$ with increase in feeding level while kidney weight decreased significantly $(P<0.05)$ with increase in feed quantity offered. Heart values of the pigs fed 2.0 and 2.5 $\mathrm{kg}$ feed daily were similar but differed significantly from those fed $1.5 \mathrm{~kg}$ feed daily. The depth of fat at first and last ribs, and subcutaneous fat depth increased significantly $(P<0.05)$ with increase in feeding level. These results showed that quantity of feed offered greatly influenced growth performance (final body weight, daily weight gain, daily feed intake and days to target weight), ham, kidney, heart and backfat composition of finishing pigs, hence, it could be used as a management tool to improve growth performance and carcass traits of pigs.
\end{abstract}

Key words: Feed quantity offered, performance, carcass yield, organs, finishing pigs

\section{Introduction}

Feeding level, diet composition and pattern of feeding are some nutritional tools used to manipulate growth rate, composition of weight gain and intramuscular fat deposition. Nutrition is vital in livestock production and management, as inadequate and poor quality ration may impair the growth potential and carcass quality. Adequate nutrition is pivotal to the success of livestock industry as feed cost alone accounts for 60-75 \% total cost of production (Okai et al., 2001; Adesehinwa et al., 2003). The choice of feeding periods for pigs is based on the nutritional requirements of the pig and economy of production (INRA, 1984; English et al., 1988). Pigs meant for pork production are designed for cost efficiency and rapid growth (Fanimo et al., 2003). Knowing what, when and how to feed and manage pigs will enable pig producers to be competitive and successfully meet the challenges encountered during production process.

The meat industry requires animals to be as lean as possible since pork with low fat content reduces human caloric intake and intramuscular fat is related to lower sensory quality traits (Fernandez et al., 1999). High 


\section{Influence of feed quantity offered on growth performance of finishing pigs}

level of carcass fat is therefore unacceptable because of the associated health problems. Feeding affects growth rate, carcass quality, amount of nutrient excreted and farmer's profitability, there is need to carry out this research in order to determine the influence of feed quantity offered on growth performance, carcass yield, organs weight and backfat composition of finishing pigs.

\section{Materials and Methods Experimental Site}

The experiment was carried out at the Piggery Unit of the Teaching and Research Farms Directorate (TREFAD), Federal University of Agriculture, Abeokuta, Ogun State, Nigeria. The farm lies within latitude $7^{\circ} 10^{\prime} \mathrm{N}$, longitude $3^{\circ} 2^{\prime} \mathrm{E}$ and altitude 76 $\mathrm{mm}$. It is located in the derived savannah zone of South-Western Nigeria. It has a humid climate with mean annual rainfall of about $1037 \mathrm{~mm}$ and temperature of about $34.7^{\circ} \mathrm{C}$. The relative humidity ranges from 63 to $96 \%$ in the rainy season (late March to October) and from 55 to $82 \%$ in the dry season (November to early March) with an annual average of $82 \%$. The seasonal distribution of annual rainfall is approximately $44.96 \mathrm{~mm}$ in the late dry season (January-March); $212.4 \mathrm{~mm}$ in the early wet season (April-June); $259.3 \mathrm{~mm}$ in the late wet season (July-September) and $48.1 \mathrm{~mm}$ in the early dry season (OctoberDecember) as recorded in Google Earth (2012).

\section{Experimental Animals and their Management}

Forty eight (48) grower Large White male pigs of 16 weeks old with mean body weight of $36.48 \pm 2.25 \mathrm{~kg}$ were randomly assigned to three experimental groups in a completely randomized design. The pigs were grouped based on weight equalization to three groups (group 1 consisting of pigs fed $2.5 \mathrm{~kg}$ feed daily, while pigs in groups 2 and 3 were offered 2.0 and $1.5 \mathrm{~kg}$ feed daily, respectively) of sixteen (16) pigs each. Each group was replicated four times with 4 pigs per replicate. Each replicate consisting of four pigs were fed and housed together in naturally ventilated pen with floor size dimension of $3 \mathrm{~m} \times 2 \mathrm{~m}$. Fresh and clean water was supplied ad libitum throughout the duration of the experiment.

\section{Experimental Design}

The pigs were randomly assigned to 3 experimental groups in a Completely Randomized Design of 16 pigs per group. The experimental groups consisted of the daily amount of dietary portion fed to each of the pigs. Pigs were offered 2.5, 2.0 or 1.5 $\mathrm{kg}$ feed daily until the pigs on replicate attained mean liveweight of $70 \mathrm{~kg}$. Each pig received $1 / 2$ of their daily ration at $08: 00 \mathrm{hr}$ and the remaining portion at 14:00 hr. Diets were formulated to meet the body requirements of growing pigs. The ration contained $16.48 \%$ crude protein and metabolisable energy of $2986.70 \mathrm{kcal}$ $\mathrm{DE} / \mathrm{kg}$ as shown in Table 1.

\section{Data Collection}

Feed intake was determined daily by subtracting the feed left-over from the feed supplied. Initial body weight of growing pigs were taken using weighing scale with a $0.05 \mathrm{~g}$ precision and documented when the pigs arrived at the experimental site and weekly records of change in body weight were subsequently taken and documented. The feed conversion ratio was calculated as ratio of feed/gain. Records of the number of days required for the pigs on each experimental group to attain average liveweight of $70 \mathrm{~kg}$ were kept.

\section{Carcass Characteristics}

Twenty four (24) pigs consisting of 8 pigs per treatment were randomly selected, 
Njoku, Aina, Sogunle, Adeyemi, and Oduguwa

Table 1: Composition of Experimental Diet (\%)

\begin{tabular}{ll}
\hline Ingredients & Fattener ration \\
\hline Maize & 47.00 \\
Groundnut cake & 14.00 \\
Wheat offal & 24.00 \\
Palm kernel cake & 12.50 \\
Bone meal & 2.00 \\
Premix* & 0.20 \\
Common salt & 0.20 \\
Lysine & 0.05 \\
Methionine & 0.05 \\
\hline TOTAL & $\mathbf{1 0 0 . 0 0}$ \\
\hline Calculated Analysis & 16.48 \\
Crude protein (\%) & 6.48 \\
Crude fibre (\%) & 0.54 \\
Calcium (\%) & 0.25 \\
Phosphorus (\%) & 2986.70 \\
ME (Kcal DE kg) &
\end{tabular}

slaughtered and analysed for carcass yield, cut-up parts and fat composition at the end of the experiment. The pigs were weighed and fasted for 16 hours, and the fasted weight of each pig meant for slaughtering was taken before they were stunned by percussion method and bled by incision using a sharp knife cutting through the jugular vein between the skull and the atlas. Complete bleeding and dehairing were done. The stomach of the pigs was opened along the greater curvature and emptied. After the removal of the visceral organs, the remaining part was measured as carcass weight and later expressed as percentage of the live weight to get the dressing percentage. The head was removed by section at the occipito-atlas joint and the feet by sawing through the hock joint at a right angle to the long axis of the leg. The carcass was divided longitudinally. The left half of the carcass was dissected as described by FAO (1991). Ham was separated by locating the division between the $2^{\text {nd }}$ and $3^{\text {rd }}$ sacral vertebrae and saw perpendicularly along axis of the ham. Shoulder of the pig was separated from the loin and belly by a straight cut between the second and third ribs and a straight cut 2.5 $\mathrm{cm}$ ventral to the ventral edge of the scapula. The parts were weighed and recorded. Back-fat depth was taken at the first and last rib using vernier calliper. The fat-free index was estimated using the formulae postulated by National Pork Producers Council (1994).

Fat-free index $=50.767+(0.035 \mathrm{x}$ hot carcass weight, $\mathrm{kg})-(8.979 \mathrm{x}$ last rib midline back-fat on hot carcass, $\mathrm{cm}$ ).

\section{Statistical Analysis}

Data were processed by one-way analysis of variance using Statistical Analyst Software (SAS, 2000) package. Significantly $(\mathrm{P}<0.05)$ different means among variables were separated using New Duncan's Multiple Range Test as contained in SAS (2000) package. 


\section{Influence of feed quantity offered on growth performance of finishing pigs}

\section{Results}

\section{Effect of feed quantity offered on performance of finishing pigs}

The effect of feed quantity offered (Table 2 ) was significant $(\mathrm{P}<0.05)$ for most of performance considered with exception of feed conversion ratio. The final body weight, daily weight gain and daily feed intake increased $(\mathrm{P}<0.05)$ significantly with increase in feed quantity offered. Whereas, days to target weight decreased significantly as feed quantity offered increased. The highest mean values for final body weight $(78.19 \mathrm{~kg})$, daily weight gain $(0.497 \mathrm{~kg})$ and daily feed intake $(2.33 \mathrm{~kg})$ were recorded for the pigs offered $2.5 \mathrm{~kg}$ feed daily, while their corresponding least values of $69.63 \mathrm{~kg}, 0.318 \mathrm{~kg}$ and $1.48 \mathrm{~kg}$, respectively were documented for the pigs offered $1.5 \mathrm{~kg}$ feed daily. The pigs offered $1.5 \mathrm{~kg}$ feed daily attained an average live weight of $70 \mathrm{~kg}$ in 108.31 days which was significantly higher $(\mathrm{P}<0.05)$ than 92.23 days (pigs offered $2.0 \mathrm{~kg}$ feed daily) and 79.94 days (pigs offered $2.5 \mathrm{~kg}$ feed daily).

Effect of quantity of feed offered on carcass characteristics of finishing pigs

The effect of quantity of feed offered on carcass characteristics of finishing pigs is documented in Table 3. The result revealed that ham, kidney and heart weights were significantly $(\mathrm{P}<0.05)$ influenced by feed quantity offered. Ham weight increased with increase in feed quantity offered while heart and kidney weights decreased with increase in feed quantity offered. The highest recorded mean value for ham was $13.41 \%$ (pigs fed $2.5 \mathrm{~kg}$ feed/day) while the least value $(11.54 \%)$ was obtained among pigs fed $1.5 \mathrm{~kg}$ feed/day. The mean values for kidney ranged from $0.11 \%$ (pigs fed 2.5 $\mathrm{kg}$ feed/day) to $0.20 \%$ (pigs fed $1.5 \mathrm{~kg}$ feed/day). Pigs fed $1.5 \mathrm{~kg}$ feed daily had highest $(\mathrm{P}<0.05)$ heart weight $(0.20 \%)$ while those fed $2.0 \mathrm{~kg}$ feed daily had the least $(0.15 \%)$. Although, no significant $(\mathrm{P}>0.05)$ differences were noted in live weight, fasted weight, bled weight, eviscerated weight, left carcass weight and shoulder weight. These parameters increased numerically with increase in feed quantity offered with the highest recorded values obtained for pigs fed $2.5 \mathrm{~kg}$ /day while those on $1.5 \mathrm{~kg}$ feed/day had the least values. The fore-legs and hind-legs weights decreased with increase in feed quantity offered. Those on $1.5 \mathrm{~kg}$ feed per day had the highest mean values while those on 2.5 $\mathrm{kg}$ feed had the least mean values.

Effect of quantity of feed offered on back fat composition of finishing pigs

The effect of quantity of feed offered on back fat composition of finishing pigs is shown in Table 4. There were no significant $(\mathrm{P}>0.05)$ differences noted for longissimus dorsi muscle "A", longissimus dorsi muscle "B", subcutaneous fat depth " $C$ " and fat free index. However, significant $(\mathrm{P}<0.05)$ differences were noted for fat at first rib, fat

Table 2: Effect of feed quantity offered on the performance of finishing pigs

\begin{tabular}{|c|c|c|c|c|}
\hline \multirow[b]{2}{*}{ Parameters } & \multicolumn{3}{|c|}{ Quantity of feed offered } & \multirow[b]{2}{*}{ SEM } \\
\hline & 1.5 & 2.0 & 2.5 & \\
\hline Initial weight (kg) & 36.25 & 37.00 & 36.19 & 2.25 \\
\hline Final weight (kg) & $69.63^{\mathrm{b}}$ & $74.93^{\mathrm{ab}}$ & $78.19^{\mathrm{a}}$ & 2.31 \\
\hline Daily weight gain (kg) & $0.318^{\mathrm{c}}$ & $0.415^{\mathrm{b}}$ & $0.497^{\mathrm{a}}$ & 0.02 \\
\hline Daily feed intake $(\mathrm{kg})$ & $1.48^{\mathrm{c}}$ & $1.87^{\mathrm{b}}$ & $2.33^{\mathrm{a}}$ & 0.11 \\
\hline Feed conversion ration & 4.91 & 4.67 & 4.61 & 0.15 \\
\hline Days to target weight & $108.31^{\mathrm{a}}$ & $92.23^{\mathrm{b}}$ & $79.94^{\mathrm{c}}$ & 3.79 \\
\hline
\end{tabular}

${ }^{\mathrm{abc}}$-means within rows having different superscripts are significantly different 
Njoku, Aina, Sogunle, Adeyemi, and Oduguwa

Table 3: Effect of feed quan tity offered on carcass characteristics of finishing male pigs

\begin{tabular}{|c|c|c|c|c|}
\hline \multirow[b]{2}{*}{ Measurements } & \multicolumn{3}{|c|}{ QUANTITY OF FEED OFFERED } & \multirow[b]{2}{*}{ SEM } \\
\hline & $1.5 \mathrm{~kg}$ & $2.0 \mathrm{~kg}$ & $2.5 \mathrm{~kg}$ & \\
\hline live weight (kg) & 71.25 & 72.00 & 75.00 & 2.54 \\
\hline Fasted weight (kg) & 69.00 & 69.25 & 72.75 & 2.33 \\
\hline Bled weight (kg) & 65.63 & 64.73 & 68.60 & 2.96 \\
\hline Hot carcass weight (kg) & 56.88 & 55.75 & 58.58 & 2.65 \\
\hline Dressing percentage $(\%)$ & 79.81 & 77.42 & 79.81 & 1.12 \\
\hline Eviscerated weight (kg) & 45.75 & 47.00 & 49.25 & 1.84 \\
\hline Left carcass weight $(\mathrm{kg})$ & 22.75 & 23.50 & 24.50 & 1.03 \\
\hline Hot carcass length $(\mathrm{cm})$ & 66.00 & 65.00 & 68.00 & 1.19 \\
\hline \multicolumn{5}{|l|}{ Cut parts (\% live weight) } \\
\hline Head weight & 9.49 & 8.85 & 9.74 & 0.42 \\
\hline Ham weight & $11.54^{\mathrm{c}}$ & $12.18^{\mathrm{ab}}$ & $13.41^{\mathrm{a}}$ & 0.55 \\
\hline Shoulder weight & 9.73 & 10.76 & 11.05 & 0.56 \\
\hline Fore-leg weight & 0.86 & 0.74 & 0.74 & 0.06 \\
\hline Hind-leg weight & 1.15 & 1.08 & 1.07 & 0.05 \\
\hline \multicolumn{5}{|c|}{ Offals weight ( $\%$ live weight) } \\
\hline Liver weight & 1.97 & 1.67 & 1.69 & 0.05 \\
\hline Lung weight & 0.75 & 0.79 & 0.83 & 0.03 \\
\hline Kidney weight & $0.20^{\mathrm{a}}$ & $0.18^{\mathrm{ab}}$ & $0.11^{\mathrm{b}}$ & 0.01 \\
\hline Heart weight & $0.20^{\mathrm{a}}$ & $0.15^{\mathrm{b}}$ & $0.16^{\mathrm{b}}$ & 0.01 \\
\hline Spleen weight & 0.13 & 0.14 & 0.13 & 0.04 \\
\hline
\end{tabular}

at last rib and subcutaneous fat at "K". The values increased $(\mathrm{P}<0.05)$ significantly with increase in feed quantity offered. The pigs on $2.5 \mathrm{~kg}$ feed daily had the highest recorded values while those on $1.5 \mathrm{~kg}$ feed per day had the least values. Fat at first rib had the mean values ranged from $3.49 \mathrm{~cm}$ (pigs offered $1.5 \mathrm{~kg}$ feed/day) to $4.12 \mathrm{~cm}$ (pigs offered $2.5 \mathrm{~kg}$ feed/day). Pigs fed 2.5 $\mathrm{kg}$ feed daily had the highest fat at last rib $(2.53 \mathrm{~cm})$ while the least value $1.68 \mathrm{~cm}$ was obtained from the pigs fed $1.5 \mathrm{~kg}$ feed per day. The values for subcutaneous fat depth "K" ranged from $1.60 \mathrm{~cm}$ (pigs fed $1.5 \mathrm{~kg}$ feed daily) to $2.47 \mathrm{~cm}$ (pigs fed $2.50 \mathrm{~kg}$ feed daily). The highest numerical values for subcutaneous fat depth " $C$ " $(1.35 \mathrm{~cm})$ were obtained in $2.5 \mathrm{~kg}$ feed /day fed pigs while their least mean values $1.03 \mathrm{~cm}$ were obtained for the pigs on $1.5 \mathrm{~kg}$ feed/day

\section{Discussion}

The experimental pigs were equalized before the commencement of the experiment. The initial weight ranged from
36.19 to $37.00 \mathrm{~kg}$. Increase in the weight gain with increasing feeding level was a function of plane of nutrition (Snetsinger, 1994), thereby resulting in adequate intake of nutrients required to sustain rapid growth and development (Esonu et al., 2002). Sufficient offering of feed to pigs is vital in optimizing overall growth performance. Garcia-Valverde et al. (2008) reported that pigs on high level of nutrition deposited both lean and fat at a faster rate than those fed moderate level of nutrition on both ageand weight- constant bases. This is in line with the observations noted in this present study where feed intake was significantly influenced by feed quantity offered. The pigs offered highest quantity of feed had the best feed intake both in total- as well as in daily feed intake. Final body weight and daily weight followed the same trend as that of feed intake with the highest observed mean values recorded by the pigs fed $2.5 \mathrm{~kg}$ feed per day. Garcia-Valverde et al. (2008) 
Influence of feed quantity offered on growth performance of finishing pigs

Table 4: Effect of quantity of feed offered on backfat composition of finishing male pigs

\begin{tabular}{|c|c|c|c|c|}
\hline \multirow[b]{2}{*}{ Measurements } & \multicolumn{3}{|c|}{ QUANTITY FEED OFFERED } & \multirow[b]{2}{*}{ SEM } \\
\hline & $1.5 \mathrm{~kg}$ & $2.0 \mathrm{~kg}$ & $2.5 \mathrm{~kg}$ & \\
\hline Live weight (kg) & 71.25 & 72.00 & 75.00 & 2.54 \\
\hline Hot carcass weight (kg) & 56.88 & 55.75 & 58.58 & 2.65 \\
\hline Longissimus dorsi muscle 'A' $(\mathrm{cm})$ & 7.92 & 7.64 & 6.63 & 0.27 \\
\hline Longissimus dorsi muscle ' $\mathrm{B}$ ' $(\mathrm{cm})$ & 4.21 & 3.96 & 3.89 & 0.24 \\
\hline Fat at first rib $(\mathrm{cm})$ & $3.49^{\mathrm{b}}$ & $3.94^{\mathrm{ab}}$ & $4.12^{\mathrm{a}}$ & 0.17 \\
\hline Fat at last rib $(\mathrm{cm})$ & $1.68^{\mathrm{b}}$ & $2.35^{\mathrm{ab}}$ & $2.53^{\mathrm{a}}$ & 0.17 \\
\hline Subcutaneous fat depth 'C' (cm) & 1.03 & 1.12 & 1.35 & 0.09 \\
\hline Subcutaneous fat depth 'K' (cm) & $1.60^{\mathrm{b}}$ & $1.93^{\mathrm{ab}}$ & $2.47^{\mathrm{a}}$ & 0.12 \\
\hline Fat free index & 49.90 & 48.52 & 47.78 & 0.60 \\
\hline \multicolumn{5}{|c|}{ ab - means within rows having different superscripts are significantly $(\mathrm{P}<0.05)$ different } \\
\hline \multicolumn{5}{|c|}{$\begin{array}{l}\text { "A" }(\mathrm{cm}) \text { Maximum width of the Longissimus dorsi muscle at the widest point } \\
\text { "B" }(\mathrm{cm}) \text { Maximum width of the Longissimus dorsi muscle at the greatest depth and } \\
\text { perpendicular to the point A measurement }\end{array}$} \\
\hline
\end{tabular}

reported that pigs responded to increase in feed offered with increased rate of weight gain and fat deposition. There was no significant difference in feed conversion ratio with increase in feed quantity offered. The pigs on daily ration of $2.5 \mathrm{~kg}$ feed had the least numerical value in feed conversion ratio, although, these pigs consumed more feed than others. The reduced feed conversion ratio with increased feed quantity offered might be linked to better feed efficiency. The increase in growth rate with increasing feed offered indicates that protein deposition had larger effect on growth rate than fat deposition. The extra feed consumed by the pigs on $2.5 \mathrm{~kg}$ feeding regime could have resulted to increase in protein deposition which mainly determines the growth rate of growing pigs. The extra gain in growth rate could be hypothesised to be proportionately higher than the increase in feed intake resulting in a reduced and therefore improved feed conversion ratio. Affentranger et al. (1996) reported better feed intake and feed efficiency in pigs fed under different feeding regimes. Feeding level, feed composition and feeding patterns have been used as tools to manipulate growth rate, weight gain, fat deposition and pork quality (Devol et al., 1988; Wood et al., 2004). So, feeding level have been applied to increase/decrease growth rate and thereby decrease/increase age at slaughter at a given body weight (Garcia-Valverde et al., 2008; Lebret, 2008a). This observation conforms to the result obtained in this present study where pigs on feed quantity of $2.5 \mathrm{~kg}$ per day attained the target weight of $70 \mathrm{~kg}$ first, followed by those on $2.0 \mathrm{~kg}$ and later by those on $1.5 \mathrm{~kg}$ daily feeding regime.

According to the growth model of de Vries and Kanis (1992) growing pigs on any nutritional plane first meet their energy requirement for maintenance. If feed intake exceeds this requirement, the surplus energy is used for protein and fat deposition. The increasing levels of feed offered reduced the age at slaughter by 14 days $(2.00 \mathrm{~kg} /$ day $)$ and 30 days $(2.50$ $\mathrm{kg}$ /day). Affentranger et al. (1996) and Lebret et al. (2001) confirmed that besides the genetic make-up of pigs, the feed composition as well as the feeding intensity can directly influence the age of slaughtering at a given body weight. From 


\section{Njoku, Aina, Sogunle, Adeyemi, and Oduguwa}

this study, the pigs were slaughtered at market weight of at least $70 \mathrm{~kg}$. The non significant mean values obtained in live weight, fasted, bled, hot carcass, left carcass weights, as well as dressing percentage and hot carcass length might be connected to the uniform weight at slaughter. This implies that feed quantity offered did not add extra variability in these parameters. Although these mean values increased with increasing feed quantity offered while age at slaughter decreased with increasing feed quantity offered. This finding is in consonance with the submission of Lebret (2008b) and Yakubu et al. (2007) that feed restriction affected fat more than lean tissue deposition when applied during finishing period. Since, body fat deposition rate increases with age, in contrast to protein deposition rate which remains almost constant during the growing-finishing periods (Reeds et al., 1993). The significant difference noted in the ham weight as percentage of live weight as well as the numerical increase in the mean value of shoulder weight with increasing levels of feeding might be linked to the slight difference noted in the growth and digestibility of the pigs given the highest quantity of feed. The pigs must have obtained sufficient amount of nutrients from the dry matter intake to compensate the energy requirement for body maintenance and as well for tissue growth. As adequate quantity of energy intake is critical to optimize lean growth and efficiency (Augenstein et al., 1997). Hence, the feeding level, pattern and protein : energy ratio of the diet, together with genetic growth potential of the pigs determine the growth rate and composition of weight gain at both whole-body and muscle level (Lebret, 2008b; Merck, 2008). Kidney and heart weight as percentages of live weight differed significantly across treatments. The observed differences suggested that compensatory growth due to improved feed conversion ratio, without increase in feed intake must have occurred (Oksbjerg et al., 2002; Therkildsen et al., 2004). Bikker et al. (1996) and Lebret (2008a) assert that at the whole body level, compensation in the rate and often efficiency of weight gain mainly results from an increase in adipose tissue and internal organ growth, but not from a higher carcass lean deposition, generally giving rise to similar carcass composition at slaughter. The observation contradicted the work of Susbilla et al. (1994); Tumova et al. (2003) and Iheukwumere et al. (2004) who did not find significant difference in heart weight.

Many research findings have shown that the level of feed offered greatly influenced the fat deposition in pigs. Feed restriction affects fat tissue more than lean tissue deposition when applied during the finishing phase. Therefore, restricted feeding leads to leaner carcasses compared with ad libitum feeding (Ellis et al., 1996; Wood et al., 1996; Lebret et al., 2001). Decrease in subcutaneous fat, adipocyte volume and lipogenic capacity in pigs is some of the effects of restricted feeding (Mersmann et al., 1981; Leymaster and Mersmann, 1991; Gondret and Lebret, 2002). The least values obtained in subcutaneous fat at first and last ribs were recorded for the pigs restricted to feeding regime of $1.5 \mathrm{~kg}$ feed per day. Hence, the importance of feed restriction on production indices over the growth period and meat quality cannot be overemphasised and this depends very much on feeding pattern, degree and duration (Campbell et al., 1983; Prince et al., 1983; Donker et al., 1986; Critser et al., 1995). The amount of feed offered per day played vital role in the growth which therefore had 


\section{Influence of feed quantity offered on growth performance of finishing pigs}

direct bearing on the quality of carcass produced. Limited-feeding led to depletion of apparent rate of glycogen as measured by muscle acidity (Mcphee and Trout, 1995) resulting to reduction in subcutaneous fat and increased in rate of lean growth (Mcphee et al., 1988). Pigs raised on restricted feeding were reported by Nguyen and Cam (2001) to have high growth rate, low back fat and high lean percentage in the carcass of their descendants, hence, the advantage of limited feeding transcends a generation.

\section{Conclusion}

The results of this study show that the growth performance (final body weight, weight gain, feed intake, days to target weight) and ham weight of finishing pigs were influenced by feed quantity offered but not the feed conversion ratio. The organs (heart and kidney) and backfat composition of the finishing pigs were also affected by feed quantity offered. Therefore, a degree of feed restriction may result in a discernible improvement in organs weight and carcass quality of finishing pigs.

\section{References}

Adesehinwa, A.O.K., Makinde, G.E.O. and Oladele, O.A. 2003. Socioeconomic characteristics of pig farmers as determinant of pig feeding pattern in Oyo State, Nigeria. Livestock Research for Rural Development 15(12)

Affentranger, P., Gerwig, C., Seewer, G. J. F., Schworer, D., Kunzi, N. 1996. Growth and carcass characteristics as well as meat and fat quality of three types of pigs under different feeding regimes. Livestock Production Science 45, 187-196.

Augenstein, M.L., Johnston, L.J., Shurson, G.C., Hawton, J.D. and
Pettigrew, J.E. 1997. Formulating farm-specific swine diets. Minnessota Extension Publication FO-5639. Minnessota Extension Service, St. Paul, MN

Bikker, P., M. W. A. Verstegen, B. Kemp, and M. W. Bosch. 1996. Performance and body composition of finishing gilts (45 to 85 kilograms) as affected by energy intake and nutrition in earlier life: I. Growth of the body and body components. Journal of Animal Science 74:806-816.

Campbell, R. G., M. R. Taverner, and D. M. Curic. 1983. Effects of feeding level from 20 to $45 \mathrm{~kg}$ on the performance and carcass composition of pigs grown to $90 \mathrm{~kg}$ live weight. Livest. Prod. Sci. 10:265-272.

Critser, D. J., P. S. Miller, and A. J. Lewis. 1995. The effects of dietary protein concentration on compensatory growth in barrows and gilts. J. Anim. Sci. 73:3376-3383.

DeVol, D.L., McKeith, F.K., Bechtel, P.J., Novakofski, F.K., Shanks, R.D., Carr, T.R. 1988. Variation in composition and palatability traits and relationships between muscle characteristics and palatability in a random sample of pork carcasses. Journal of Animal Science 66:385395.

de Vries, A.G. and Kanis, E. 1992. A growth model to estimate economic values for food intake capacity in pigs. Animal Production 55(2):241246

Donker, R..A., Denhartog, L.A., Brascamp, E.W., Merks, J.W.M., Noordewier, G.J., and Buiting, G.A.J. 1986. Restriction of feed intake to optimise the overall 
performance and composition of pigs. Livest. Prod. Sci.15, 353-365.

Ellis, M., Webb, A.J., Avery, P.J. and Brown, I. 1996. The influence of terminal sire genotype, sex, slaughter weight, feeding regime and slaughterhouse on growth performance and carcass and meat quality in pigs and on the organoleptic properties of fresh pork. Anim. Sci. 62:521-530.

English, P. R., Fowler, S., Baxter, S. and Smith, B. 1988. The growing and finishing pigs: Improving efficiency. Farming Press Books, Ipswich UK.

Esonu, B.O., Iheukwumere, F.I., Emenalom, O.O., Uchegbu, M.C. and Etuk, E.B. 2002. Performance, nutrient utilization and organ characteristics of broiler finishers fed microdesmis puberula leaf meal. Livestock Research for Rural $\mathrm{d}$ e $\mathrm{v}$ e 1 o http://www.cipav.org.co/1lrd1416/es on146.htm.

Fanimo, A.O, Oduguwa, O.O, Adesehinwa, A.O.K, Owoeye, E.Y, Babatunde, O.S, 2003 Response of weaner pigs to feed rationing and frequency of feeding. Livestock Research for Rural Development 15(6)

Fernandez, X., Monin, G., Talmant, A., Mourot, J. and Lebret, B. 1999. Influence of intramuscular fat content on the quality of pig meat. Meat Science 53:59-72

Food and Agriculture Organization (FAO), 1991. Guidelines for slaughtering meat cutting and further $\begin{array}{lllllllllllllll}\mathrm{p} & \mathrm{r} & \mathrm{o} & \mathrm{c} & \mathrm{e} & \mathrm{s} & \mathrm{s} & \mathrm{i} & \mathrm{n} & \mathrm{g} & \text {. }\end{array}$ http://www.fao.org/DOCREP/004/T 0279E/T0279E00.HTM

Garcia-Valverde, R., Barea, R., Lara, L., Nieto, R. and Aguilera, J.F. 2008. The effects of feeding level upon protein and fat deposition in Iberian heavy pigs. Livestock Science 114: 263-273

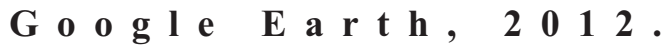
http://www.google.earth

Gondret, F. and Lebret, B. 2002. Feeding intensity and dietary protein level affect adipocyte cellularity and lipogenic capacity of muscle homogenates in growing pigs, without modification of the expression of sterol regulatory element binding protein. J. Anim. Sci. 80:3184-3193

Iheukwumere, F.C., Esonu, B.O and Ogbuji, L.A. 2004. Effect of quantitative feed restriction on the performance, carcass, organ weight and meat quality of broiler finisher birds. Nigeria Agricultural Journal.35:127-132

INRA, 1984. L'Alimentation des animaux mono gastriques: porc, lapin, volailles. (Institut National de la Recherche Agronomique) INRA Paris.

Lebret, B., Juin, H., Noblet, J. and Bonneau M. 2001. The effects of two methods of increasing age at slaughter weight on carcass and muscle traits and meat sensory quality in pigs. Anim. Sci. 72:87-94.

Lebret, B. 2008a. The response of various muscle types to a restriction realimentation feeding strategy in growing pigs. Journal of Animal Science 1:849-857

Lebret, B. 2008b. Effects of feeding and rearing systems on growth, carcass traits and meat quality in pigs. Journal of Animal Science 2:15481558

Leymaster, K.A. and Mersmann, H.J. 1991. Effect of limited feed intake on 
Influence of feed quantity offered on growth performance of finishing pigs

growth of subcutaneous adipose tissue layers and on carcass composition in swine. Journal of Animal Science 69:2837-2843

Mcphee, C.P., Rathmell, G.A., Daniels, L.J. and Cameron N.D. 1988. Selection for pigs for increased lean growth rate on a time-based feeding scale. Animal Production 47:149156.

Mcphee, C.P. and Trout, G.R. 1995. The effects of selection for lean growth and the halothane allele on carcass and meat quality of pigs transported long and short distances to slaughter. Livest. Prod. Sci. 42: 1, 55-62.

Merck \& Co., Inc. 2008. Whitehouse Station, NJ USA.published in educational partnership with Merial Ltd.

Mersmann, H J, Allen C D, Chai E Y, Brown $L$ J and Fogg T J 1981. Factors influencing the lipogenic rate in swine adipose tissue. J. Anim. Sci. 52:1298-1305

National Pork Producers Council. 1994. "Procedures to evaluate market hogs." National Pork Producers Council, Des Moines, Iowa

Nguyen, H.N. and Cam, P.M. 2001. Selection for efficient lean growth on restricted feeding in large white pigs. Breeding and Feeding pigs in Australia and Vietnam - ACIAR 9423.

Okai, D.B., Tuah, A.K. and OwusuAsiedu, A. 2001. Phase feeding of pigs using Obatanpa- A quality protein maize. Journal of the Kwane Nkrumah University of Science and Technology 2(1-3):5-11

Oksbjerg, N., Sorensen, M. T. and Vester ga a rd, M. 2002 . Compensatory growth and its effect on muscularity and technological meat quality in growing pigs. Acta Agriculture and Scandinavica Animal Science

Prince, T. J., S. B. Jungst, and D. L. Kuhlers. 1983. Compensatory responses to short- term feed restriction during the growing period in swine. J. Anim. Sci. 56:846-852.

Reeds, P.J., Burrin, D.G., Davis, T.A., Fiorotto, M.A., Mersmann, H.J. and Pond, W.G. 1993. Growth regulation with particular reference to the pig. In. Hollis G.R. (ed.) Growth of the pig. Chapter 1, pp 1-33, CAB international, Wallingford, Oxon, UK

SAS, 2000. SAS/STAT ${ }^{\circledR}$ User's guide (Version 8, 4th edition), SAS Institute Inc. Cary NC

Snetsinger, D. 1994. Limiting feeding of egg strain layers as influenced by cage density and social order. Poultry Science 53: 1073-1079

Susbilla, J.P., Frankel, T.L., Parkinson, G. and Gow, C.B. 1994. Weight of internal organs and carcass yield of early food restricted broilers. British Poultry Science 35: 677-685.

Therkildsen, M., Vestergaard, M., Busk, H., Jensen, M. T., Riis, B., Karlsson, A. H., Kristensen, L., Ertbjerg, P. and Oksbjerg, N. 2004 . Compensatory growth in slaughter pigs-in vitro muscle protein turnover at slaughter, circulating IGF-I, performance and carcass quality. Livestock Production Science 88:63-75.

Tumova, E., V. Skrivanova and M. Skrivan, 2003. Effect of restricted feeding time and quantitative restriction in growing rabbits. Arch. Geflugelkde, 67: 182-190.

Wood, J. D., Brown, S. N., Nute, G. R., Whittington, F. M., Perry, A.M., Johnson, S. P. and Enser, M. 1996. 
Effects of breed, feed level and conditioning time on the tenderness of pork. Meat Science 44:105-112.

Wood, J.D., Nute, G.R., Richardson, R.I., Whittington, F.M., Southwood, O., Plastow, G., Mansbridge, R., da Costa, N. and Chang, K.C. 2004. Effects of breed, diet and muscle on fat deposition and eating quality in pigs. Meat Science. 67: 651-667
Yakubu, A., Salako,A.E., Ladokun A.O., Adua, M.M. and Bature, T.U.K. 2007. Effects of feed restriction on performance, carcass yield, relative organ weights and some linear body measurements of weaner rabbits. Pakistan Journal of Nutrition 6 (4): 391-396

Received: 1st August, 2012

Accepted: 31st December, 2012 